\title{
SIMULAKRA BAUDRILLARD DALAM MULTIDIMENSI POSMODERNISME: KAJIAN FOTOGRAFI MAKANAN DALAM MEDIA SOSIAL INSTAGRAM
}

\author{
Adya Arsita \\ Dosen Jurusan Fotografi, Fakultas Seni Media Rekam, ISI Yogyakarta \\ Jalan Parangtritis Km 6,5 Sewon, Bantul, DIY \\ No. HP.: 08983709385; E-mail: adya.arsita@yahoo.com
}

\begin{abstract}
Abstrak
Makanan kini dipandang dengan sudut pandang yang berbeda karena tidak lagi sekadar sebagai kebutuhan pokok, tetapi telah dimaknai jauh dari fungsi utamanya. Telah sekian lama makanan menjadi simbol kemakmuran orang yang berpunya sejak abad ke-16 dan ke-17 yang ditunjukkan dalam lukisan-lukisan pada masa itu, yang kini kemudian meraih masa gemilangnya melalui berbagai tayangan di televisi, majalah, dan buku masakan. Makanan tidak lagi sekadar apa yang dimakan, tetapi menjadi sesuatu yang dipamerkan dan berkembang menjadi gaya hidup. Seiring dengan berkembangnya teknologi komunikasi, orang cenderung mengumbar kegemarannya akan makanan melalui berbagai media sosial, salah satu yang terkenal adalah Instagram. Visualisasi makanan telah diekspos sedemikian rupa dari menu rumahan yang sederhana hingga makanan kelas atas yang biasanya tersaji di restoran mewah. Tulisan ini membahas banyaknya foto makanan yang diunggah ke dalam berbagai akun Instagram dan kemudian akan dicoba untuk menemukan bagaimana unggahan tersebut memengaruhi keseharian manusia. Metode yang digunakan adalah mengaitkan teori simulakra dari Baudrillard dengan pendekatan multidimensi posmodernisme. Akun Instagram dipilih secara acak berdasarkan tampilan enam frame pertamanya yang menampilkan foto-foto makanan, yang kemudian foto-foto tersebut dianalisis menggunakan kajian simulakra dari Baudrillard. Hasil temuan dari analisis menunjukkan bahwa orang tidak lagi mengonsumsi sesuatu (makanan) sesuai fungsinya, tanpa disadari mereka telah mengonsumsi sebuah tanda yang akhirnya akan meletakkan mereka ke dalam hierarki, kelompok, dan kelas dengan kemampuan mengonsumsi yang sama. Instagram merupakan salah satu media sosial yang menggunakan foto sebagai instrumen untuk berkembangnya budaya visual yang makin memperkuat berlangsungnya simulakra dalam keseharian, yang memisahkan objek dari apa yang seharusnya direpresentasikannya hingga ke ambang batas nihilisme dan orang tidak bisa lagi mengenali apa yang sesungguhnya mereka apresiasi.
\end{abstract}

Kata kunci: simulakra Baudrillard, multidimensi posmodernisme, kajian foto makanan, media sosial, Instagram

\section{Abstract}

Baudrillard's Simulacra in Multidimensional Postmodernism: an Analysis of Food Photography in Social Media Instagram. Food has been seen in different views nowadays, it is not merely one of the staples, but it has gone far beyond its primary function. Food has long been a symbol of prosperity of the haves since the $16^{\text {th }}$ until the $17^{\text {th }}$ century through paintings, which later these days regains its triumph in the abundant TV shows, magazines and cook books. Food is no longer what we eat, but it is something to show off and lately it has become a lifestyle. Along with the advanced communication technology, people tend to flaunt their food fetish through various social media, one that has become so popular is Instagram. The visuality of food has been vividly exposed from simple home cooking menu to high-end foods such those served in fine dining restaurants. This article tries to analyze the massive photographs of food uploaded in several random accounts of Instagram, and then tries to find out to what extent they influence our everyday life. The method employed is Baudrillard's simulacra with a hint of approach of multidimensional postmodernism. Random accounts of 
Instagram were chosen based on their first six frames or feeds all exposing food, then those photographs were elaborated and analyzed using Baudrillard's simulacra. The findings show that people no longer consume something (food) as it is, but they have consumed 'signs'or the prestige symbols embedded in that object. The act of consuming signs will finally put them in certain hierarchy, groups, and classes with the same interest and ability to consume the same sign in the same way. Instagram as one of the social media using the photograph as the instrument in blossoming the visual culture strengthens the simulacra that happens in daily basis, that it seems separating the object from what it should represent until it fades to nihilism and people can hardly recognize what they really appreciate.

Keywords: Baudrillard's simulacra, multidimensional postmodernism, food photography, social media, Instagram

\section{PENDAHULUAN}

Pada era yang serba cepat dan maju ini, informasi tidak perlu susah payah dicari, karena justru informasilah yang sekarang seolah datang menghampiri kita dengan sekali sentuhan jari. Zaman semacam inilah yang dinamakan 'desa global' atau 'global village' oleh (McLuhan, 1964). Konsep desa global yang diperkenalkan oleh McLuhan ini memuat pemahaman tentang masyarakat yang mulai masif dengan keberadaan teknologi (internet). Desa global yang dimaksud oleh McLuhan ini dianalogikan sebagai sebuah komunitas masyarakat yang saling 'sepaham' dalam kemajemukannya dan hal ini merupakan salah satu semangat yang dikobarkan dalam era postmodernism atau posmodernisme. Posmodernisme adalah sebuah aliran pemikiran dan berkembang menjadi semacam paradigma baru yang merupakan antitesis dari modernisme yang dinilai telah gagal dan tidak lagi relevan dengan perkembangan zaman.

Dalam arus posmodernisme, media massa berkembang dengan cepat. Media bisa membawa pengaruh buruk dan pada saat yang bersamaan bisa juga membawa pengaruh baik. Media sosial yang tengah bersinar pamornya saat ini adalah Instagram. Dalam media sosial Instagram, beragam paparan visual dihadirkan di sana, dari online shop dengan visualisasi dagangan mereka, public figure dengan visualisasi kesibukannya, pegiat dan penggiat fotografi dengan ruang pamer virtual mereka, visual diary para keluarga dengan keseharian mereka hingga visualisasi berbagai jenis makanan semua campur aduk memenuhi feeds Instagram.

Instagram adalah sebuah aplikasi berbagi foto yang memungkinkan penggunanya untuk mengambil foto, menerapkan filter digital, dan mengunggah serta membagikannya ke berbagai layanan media sosial, termasuk milik Instagram sendiri. Satu fitur yang unik di Instagram adalah membingkai foto menjadi bentuk persegi sehingga terlihat seperti hasil kamera Kodak Instamatic dan Polaroid. Hal ini berbeda dengan rasio aspek 4:3 yang umum digunakan oleh kamera di peranti bergerak. Maka tidak heran bila ikon Instagram menyerupai kamera Polaroid berwarna kecokelatan (Komputer, 2015). Dikarenakan Instagram merupakan sebuah aplikasi untuk berbagi foto, semua pengguna seolah berlomba untuk mengunggah foto mereka tanpa memedulikan apakah kualitas foto mereka secara teknis layak unggah ataupun tidak. Kegiatan mengunggah foto ini makin hari makin menjadi sebuah 'kebiasaan' bagi para penggunanya, bukan lagi sebagai sekadar hobi. Hal yang cukup menarik untuk diamati dari unggahan para pengguna Instagram adalah banyaknya foto makanan yang ditampilkan dalam berbagai cara dengan rentang menu atau jenis makanan yang cukup berbeda jauh.

Sebelum foto makanan begitu marak hadir di media sosial dan memiliki prestisenya tersendiri, foto fashion telah jauh terlebih dahulu mencuri 
perhatian khalayak. Dalam budaya visual, fashion selalu menjadi perbincangan hangat yang tidak akan kunjung usai. Fashion hadir penuh tanda dan makna yang kemudian tanda dan makna itu direproduksi ulang oleh penikmat fashion. Makanan, yang sejatinya merupakan kebutuhan pokok manusia dan merupakan 'rahasia' masing-masing individu dalam ranah domestik, kini hadir bagai sebuah seni visual yang memenuhi media sosial. Dengan media fotografi, makanan menjadi sesuatu yang indah, menggiurkan, menimbulkan selera, dan menggugah rasa untuk memandang dan mencicipinya. Jenis makanan yang diunggah fotonya ke dalam Instagram bisa sangat bervariasi, dari makanan ala restoran yang high class dari segi harga dan penampilannya hingga makanan ala 'ndeso' semacam sayur-mayur dan berbagai masakan rumahan (home cooking) lainnya. Bila beberapa waktu lalu masyarakat dibombardir dengan berbagai jenis acara masakmemasak di televisi dan tebaran resep-resep di majalah dan tabloid, sehingga pemirsa seringkali mengidentifikasi diri mereka sebagai koki (chef), kini mereka seolah memasuki tahap baru, yaitu menata dan mengabadikan hasil masakan mereka dengan media fotografi dan kemudian mengunggahnya ke media sosial Instagram.

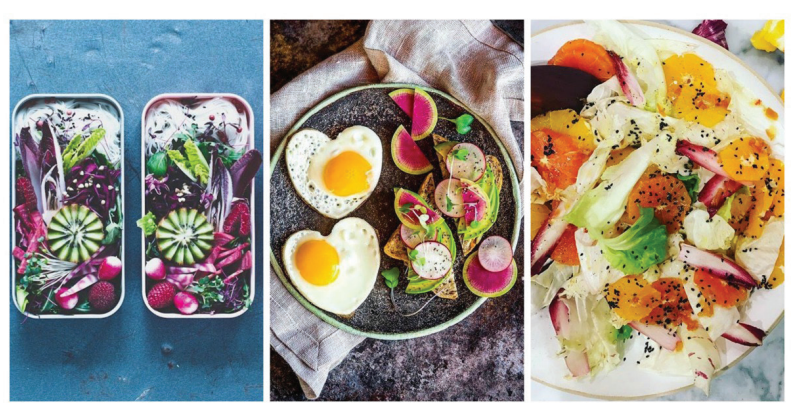

Sumber : http://aisleperfect.com/living/Instagramaccounts-for-health-conscious-foodies (diakses pada 20 Agustus 2017, pukul 15.00 WIB

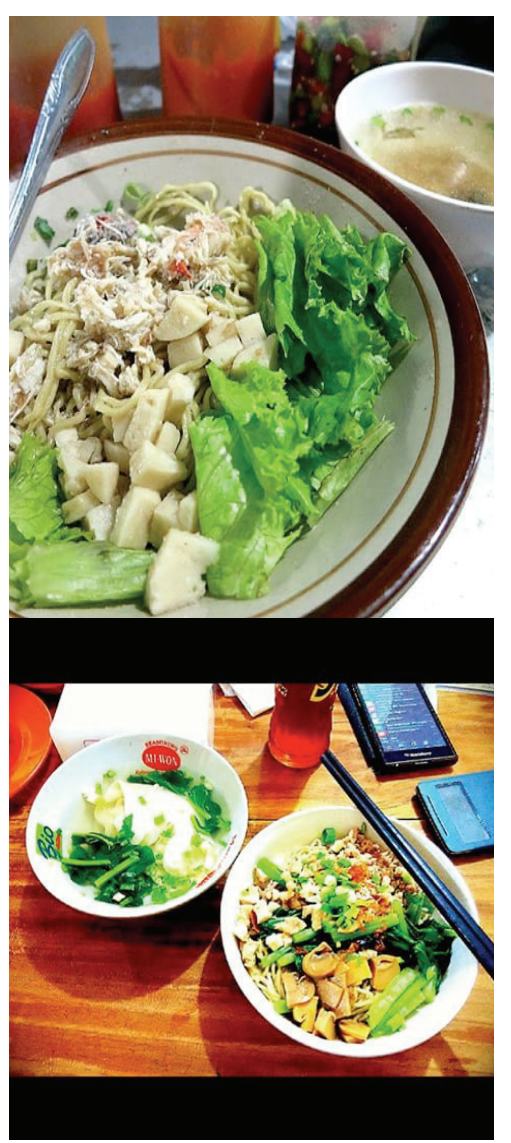

Sumber ; http://www.imgrum.org/user/redwings. ayomakan/2013209265/990561010417052258

(diakses pada 20 Agustus 2017, pukul 15.00 WIB)

Dalam kehidupan sehari-hari banyak ditemui fenomena posmodernisme yang bersinggungan dengan narasi besar lainnya dan saling menguatkan satu sama lain. Berkelindannya akses internet dan media sosial dengan dunia fotografi sudah menjadi hal yang tidak terpisahkan dari kehidupan manusia pada masa sekarang ini. Hedonisme masyarakat bagai diumbar dengan bebas dan muncullah istilah enthusiast yang tersegmentasi di media sosial, dari fashion enthusiast hingga food enthusiast. Makanan divisualisasikan secara begitu rupa dengan media fotografi, ditandai dengan tagartagar khusus (misal: \#foodenthusiast, \#foodism, \#ayomakan, \#foodoftheday), diapresiasi dengan fitur like dan comment dalam Instagram, diunggah ulang dengan aplikasi repost application atau regram dan mungkin juga diberlakukan beberapa penerapan olah digital. Tanda dan realitas menjadi kabur 
dikarenakan banyaknya simulasi tanda di sana-sini. Sesungguhnya makanan difoto untuk menggugah selera makan atau sekadar untuk dipandang, foto makanan diunggah untuk berbagi informasi atau sekadar pamer demi prestise. Representasi dari halhal riil kemudian tampak lebih mendominasi. Oleh karena itu, tujuan tulisan ini adalah untuk melihat bagaimana posmodernisme hadir dalam consumer society-nya Jean Baudrillard dengan simulakranya yang mempunyai pengaruh besar dalam gaya hidup manusia, dan khususnya perkembangan fotografi makanan di Indonesia yang direpresentasikan dalam unggahan foto-foto makanan di Instagram.

\section{METODE PENELITIAN}

Metode yang akan dipakai dalam penelitian ini adalah metode kualitatif, yaitu memaparkan fakta berdasarkan data-data dan sumber pustaka. Penelitiankualitatifmemilikiprinsipyangrealitasnya bersifat menyeluruh sebagai hasil konstruksi dari pemahaman yang secara interaktif dan tidak terpisahkan, dibangun dari hubungan antara peneliti dan objek penelitian, tanpa kecenderungan untuk menghasilkan suatu generalisasi karena realitas budaya adalah sesuatu yang cair dan fenomenanya bersifat polisemik sehingga berada pada wilayah interpretatif (Endraswara, 2003). Sifat menyeluruh dalam metode kualitatif menganggap bahwa setiap petunjuk adalah penting untuk dianalisis.

Sebuah metode penelitian dimasukkan ke dalam kategori kualitatifjika analisis yang dilakukan juga kualitatif (Alasuutari, 1995). Variabel-variabel yang digunakan bukanlah nominal seperti layaknya dalam penelitian kuantitatif, walau tidak menutup kemungkinan adanya penomoran dan pelabelan variabel. Potongan-potongan informasi yang didapat kemudian dianalisis sebagai satu kesatuan yang utuh karena analisis kualitatif memerlukan keabsolutan yang berbeda dari penelitian statistik. Beberapa data bisa saja dihilangkan atau justru digunakan semua untuk kepentingan penelitian, hal tersebut dilakukan sesuai dengan interpetasi peneliti. Lingkup populasi dalam kajian ini adalah foto-foto makanan yang diambil secara acak dari beberapa akun Instagram dengan feeds unggahan foto yang mayoritas menampilkan makanan.

Foto-foto makanan tersebut kemudian dianalisis melalui tahapan pemilahan foto-foto tertentu yang dianggap mewakili tren kekinian. Langkah selanjutnya adalah melihat muatan-muatan pesan yang direpresentasikan dalam visualisasinya dengan pemahaman simulakra dan posmodernisme. Kesimpulan diharapkan dapat ditarik dari hadirnya berbagai jenis visualisasi foto makanan yang berkorelasi dengan simulakra, bahwa masyarakat lebih mengonsumsi tanda yang terlekat pada suatu objek sebagai manifestasi dari simulasi-simulasi dalam masyarakat global.

\section{LANDASAN TEORI}

\section{Posmodernisme}

Posmodernisme hadir dengan mengusung kepalsuan dan hal-hal semu yang seringkali berada pada garis abu-abu logika seseorang. Lyotard menyatakan bahwa zaman posmodernisme ini merupakan sebuah masa di mana orang meragukan metanarasi, meniadakan sistem-sistem filosofis yang lampau, dan menciptakan narasi-narasi mikro sesuai versi masing-masing individu (Berger, 2010). Pada zaman ini semua serba ada, tersedia, dan bebas karena posmodernisme menganut paham kebebasan. Posmodernisme sebetulnya sudah dikenal luas di dunia Barat sekitar tahun 1950an dan kemudian menjadi semakin populer pada tahun 1970-an. Istilah posmodernisme hadir untuk dipertentangkan dengan modernisme, yang dalam dunia seni, posmodernisme muncul dengan berbagai instrumen dan tanda-tandanya sebagai support atas kebudayaan massal.

Posmodernisme agak sulit didefinisikan 
dengan runut karena posmodernisme seolah menolak pendefinisian terhadap segala sesuatu hal yang dikarenakan pendefinisiannya menganggap adanya suatu nihilisme dan tanpa aturan. Posmodernisme adalah sebuah aliran pemikiran dan berkembang menjadi semacam paradigma baru yang merupakan antitesis dari modernisme. Modernisme sendiri ditandai oleh kepercayaan penuh pada keunggulan sains, teknologi, dan pola hidup sekuler, ternyata dianggap tidak cukup kokoh untuk menopang era industrialisasi dan kapitalisme yang dikampanyekan dapat membawa kesejahteraan dalam kehidupan masyarakat.

Dalam arus posmodernisme, media massa berkembang dengan cepat. Media bisa membawa pengaruh buruk dan pada saat yang bersamaan bisa juga membawa pengaruh baik. Untuk memahami macam media yang berdampak baik atau buruk, diperlukan interpretasi rasional pada kondisi sosial yang kian berkembang pesat dikarenakan adanya penyebaran budaya media yang bersifat global. Namun, tidak banyak yang bisa memahami 'struktur makna' yang disebarluaskan media ke dalam sistem kehidupan sehari-hari. Penyebab hal yang demikian adalah karena adanya aspek 'kelumrahan' atau seolaholah 'alamiah' (natural), bahwa memang semuanya begitu adanya. Setiap hari manusia cenderung beraktivitas rutin layaknya robot yang sudah terbiasa dengan suatu program tertentu. Maka tidak salah bila (McLuhan, 1964) mengatakan bahwa media merupakan perpanjangan tidak sadar dari proses indrawi dan kognitif yang tertanam di dalam diri seseorang. Melalui berbagai macam media massa pula, perkembangan tren zaman atau teknologi yang paling terkini bisa terus diikuti. George Gerbner berpendapat bahwa media massa tidak hanya mentransmisikan informasi ke seluruh penjuru dunia, namun media masa juga bisa membuat agenda dan hal-hal yang penting untuk kita ketahui (Littlejohn, 2008).

Hal-hal yang bisa dikonsumsi melalui media sangatlah beraneka rupa, bahkan mungkin hampir semua hal yang dikonsumsi dalam kehidupan manusia semuanya tanpa terkecuali merupakan campur tangan media. Kebutuhan dasar manusia yang seolah merupakan hal paling pribadi pun kini terinterferensi dengan media, misalnya jenis sabun mandi hingga makanan. Untuk mencermati posmodernisme media dengan kecenderungan simulakranya, Jean Baudrillard mempunyai teori semiotik yang khusus membahas media. Teorinya adalah mengenai masyarakat posmodern berdasarkan asumsi utama bahwa media, simulasi, dan apa yang ia sebut 'cyberblitz' telah mengonstitusi bidang pengalaman baru, tahapan sejarah, dan tipe masyarakat yang baru.

\section{Fotografi dan Media Sosial}

Kemajuan dunia fotogafi kini seolah tidak melulu sekadar perkara teknis, yang dulu dipahami bahwa seseorang haruslah mempunyai piranti alat fotografi, berupa kamera yang memadai untuk dioperasikan dengan baik dan benar serta dapat menghasilkan gambar yang bagus. Masyarakat awam nonpraktisi fotografi kini menemukan euphoria berfotografi dalam bentuk ponsel pintar. Tidak hanya orang awam, bahkan banyak ahli fotografi yang tidak diragukan lagi dengan teknik fotografinya menambahkan ponsel pintar berkamera yang canggih sebagai salah satu media berkarya. Ponsel pintar dengan kecanggihan tekonologi fotografinya kini tidak lagi menjadi sekadar angan dikarenakan produsen makin memperlebar variasi harga dan spesifikasi ponsel pintar. Dengan demikian, siapa pun bisa memiliki ponsel pintar berkamera. Semakin mahal harganya, tentu saja spesifikasi ponsel dan kameranya akan bertambah tinggi pula, bahkan beberapa ponsel pintar menawarkan fitur megapiksel kameranya jauh melebihi kamera foto konvensional yang sudah dianggap sangat memadai oleh para praktisi dan pegiat fotografi. Variasi dan 
ragam ponsel pintar berkamera memicu naiknya minat masyarakat terhadap dunia fotografi, dari swafoto, fotografi fashion, produk, lanskap, hingga makanan. Hasil karya foto tersebut bagi kebanyakan orang akan diunggah di media sosial yang mereka miliki. Beberapa kamera DSLR bahkan memiliki fitur untuk terkoneksi dengan internet melalui wifi sehingga berbagi foto ke dalam jejaring sosial semakin dipermudah.

Masyarakat sekarang cenderung menjadi 'hamba' media sosial, bahwa mereka merasa mampu bersosialisasi melalui media sosial, merasa perlu untuk menunjukkan eksistensi dirinya, dan tidak sedikit yang menjadi 'kecanduan' dengan media sosial. Aktivitas harian yang sebetulnya tidak perlu diketahui oleh tetangga sebelah rumah, kini justru diunggah ke media sosial dan bahkan sudah dianggap sebagai suatu kelumrahan yang tidak pernah dipertanyakan. Media sosial merupakan lahan yang subur bagi menjamurnya paparan visual, khususnya fotografi. Beragam jenis fotografi memenuhi tiap jenis media sosial, terutama karena media sosial bisa saling terkait secara langsung satu sama lain dalam suatu jejaring sosial, maka persebaran foto menjadi tidak terbendung di dunia maya. Instagram, sebagai salah satu media sosial yang kini sangat digemari masyarakat tanpa memandang usia, gender dan strata sosial, menjadi salah satu instrumen yang kuat untuk membentuk suatu komunitas virtual secara global seperti diteorikan oleh McLuhan dengan 'global village'nya. Melalui media sosial Instagram pula, konon kabarnya masyarakat menjadi lebih 'terupdate' dengan segala macam informasi, dari berita politik yang resmi, dekorasi dan pernik rumah, tempat wisata terpopuler, wisata kuliner, hingga propaganda-propaganda yang penuh hasutan.

\section{Simulakra}

Untuk memahami tanda dan makna yang terkandung di dalam teks-teks media, pendekatan semiotik bisa dilakukan. Ilmu penandaan atau semiotik dapat memberikan pandangan yang lebih luas dan dalam terhadap tanda dan simbol yang muncul dalam kehidupan sehari-hari. Ilmu semiotik merupakan alat yang tepat untuk mempelajari dampak yang terjadi dari media massa. Semiotik mementingkan content dari sebuah tanda yang merupakan produk dari penggunaan tanda. Menilik hubungan antara media dan semiotik, akan lebih tepat jika dilihat dari kacamata Jean Baudrillard tentang teori semiotik yang khusus membahas media. Baudrillard berpendapat bahwa tanda telah jauh dipisahkan dari objek yang direpresentasinya, dan media seolah menggiatkan proses pemisahan tersebut hingga ambang nihilisme. Seharusnya sebuah tanda secara sederhana dapat merepresentasi suatu objek tertentu, misalnya tas tenteng mungil berwarna keemasan dengan akses bunga-bunga merepresentasikanaksesorisperempuan.Haltersebut yang oleh Baudrillard disebut sebagai symbolic order - yaitu objek dan tanda saling berkaitan satu sama lain. Sementara itu, counterfeits - imitasi, yaitu objek tidak sepenuhnya terepresentasikan oleh tanda yang hadir (Littlejohn, 2008). Pemikiran Baudrillard ini bisa menjadi ancaman yang serius bagi orang kebanyakan karena ia adalah seorang 'penipu intelektual posmodernisme' yang ulung dalam menghidupkan kata-kata tanpa makna dan mengagungkan nihilisme moral (Sokal, 1998).

Dalam era simulasi sekarang ini, manusia dihadapkan pada makna kehidupan yang seolah-olah semu belaka tatkala tanda tidak lagi mewakili sesuatu apa pun, tetapi justru seolaholah menciptakan kenyataan baru (Edkins, 2009). Simulasi-simulasi yang tercipta bagaikan menentukan apa dan siapa manusia itu. Simulasi tersebut erat kaitannya dengan komoditas dan komodifikasi, yaitu segala hal dikapitalisasi. Sosial budaya tempat kita tinggal akan menentukan apa yang kita kehendaki dan butuhkan yang kemudian 
akan merembet pada masalah cita rasa, pilihan, dan keinginan (Littlejohn, 2008). Maka kemudian aktivitas mengonsumsi itu sendiri akan menjadi lebih penting daripada apa yang dikonsumsi atau apa yang sesungguhnya diperlukan.

Kegiatan mengonsumsi produk sosial budaya dan apa yang dikonsumsi dapat menjadi representasi akan siapa atau apa sesungguhnya seorang individu itu dan bagaimana ia akan diposisikan dalam masyarakatnya. Menurut Fiske, representasi adalah segala sesuatu yang merujuk pada proses yang dengannya realitas disampaikan dalam komunikasi baik melalui kata-kata, bunyi, citra, dan kombinasi di antaranya (Fiske, 1990). Hall membagi representasi dalam dua kategori, yang pertama adalah representasi mental yang bersifat abstrak, dan yang kedua adalah representasi bahasa yang mempunyai peranan penting dalam penyampaian makna (Hall, 1997). Maka untuk bisa memahami konsep mental yang abstrak itu diperlukan konvensi bahasa agar bisa mengonstruksi makna yang selaras dengan nilai sosial budaya setempat.

\section{PEMBAHASAN}

Makanan kini bukan lagi sekadar hidangan yang disantap sebagai penghilang lapar atau sebagai kebutuhan utama untuk mendapatkan asupan gizi yang cukup. Makanan rumahan seberapa pun sederhananya tidak lagi disembunyikan di meja makan atau dapur. Kegiatan makan di emperan toko dan warung-warung makan sederhana di pinggir sawah atau kebun kini bisa diceritakan ke seluruh penjuru dunia dan bahkan menjadi viral. Makanan telah menjadi sebuah produk budaya visual yang kian hari makin kental. Makanan yang termediasikan melalui teknologi fotografi dan media sosial menjadi penuh dengan kode tertentu, entah itu kode kemapanan seseorang yang mengarah kepada prestise konsumennya, atau bisa juga sebagai kode kondisi mental dan psikologis mereka. Sepotong pisang goreng dahulu biasa dimaknai sebagai suguhan makanan di desa, sementara sushi dahulu 'ditakuti' masyarakat kelas ekonomi menengah karena harganya. Dilihat dalam perkembangannya sekarang, pisang dan sushi menjadi jenis hidangan yang setara dan bahkan bisa jadi di beberapa tempat pisang dan sushi seolah 'bertukar' tempat dan prestise. Pisang goreng ditata sedemikian rupa dalam sebuah piring saji dan dihidangkan di sebuah rumah makan yang terkenal bisa menaikkan prestise makanan tersebut. Sebaliknya, sushi yang merupakan makanan khas dari Jepang yang disajikan di sebuah tempat makan kaki lima menjadikannya terjangkau untuk dikonsumsi kalangan masyarakat kelas ekonomi menengah walaupun menurunkan prestise jenis makanannya.

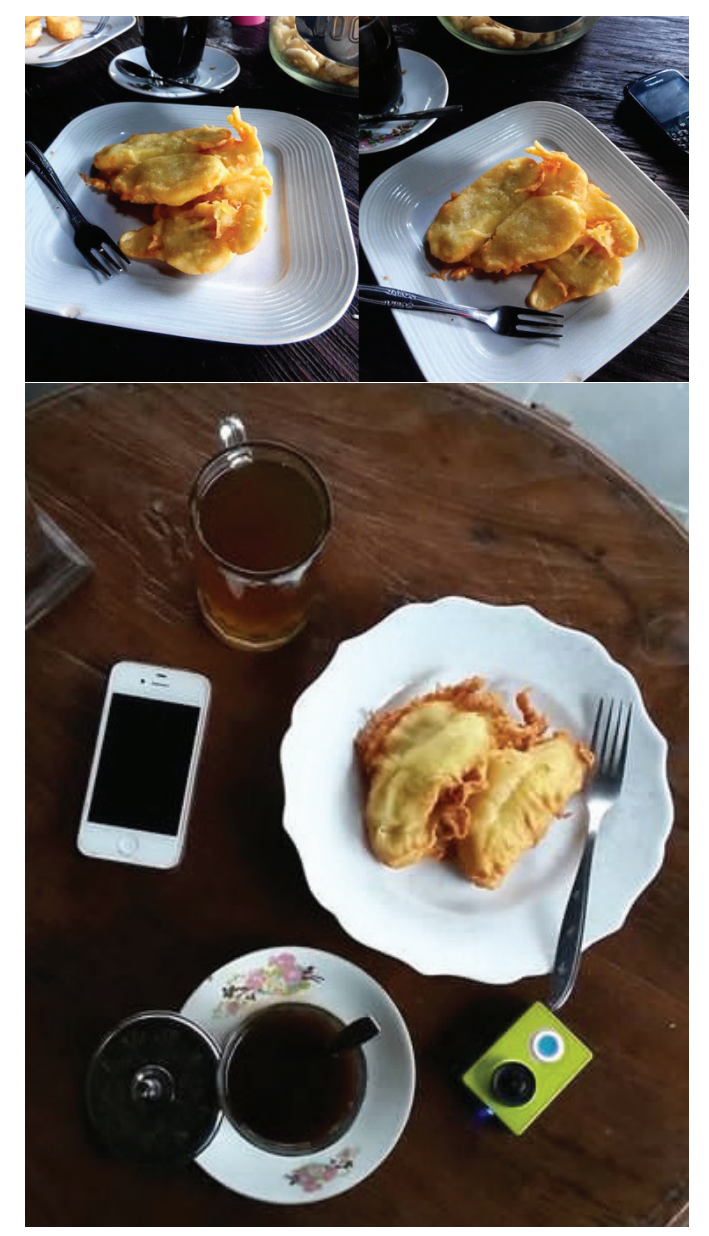

Sumber: https://kopiklotokpakem.blogspot. co.id/2016/03/pisang-goreng-kopi-klotok-pakem.html (diakses pada 11 Agustus 2017, 06.00 WIB) 
Food presentation dan food styling merupakan cara menata dan menghidangkan makanan yang merupakan unsur penting dalam fotografi makanan. Penataan makanan di piringpiring saji itulah yang kemudian menjadi lebih penting daripada jenis, kandungan gizi, dan harga makanan tersebut. Jauh sebelum era fotografi, pada suatu masa ketika seni lukis berkembang pesat pada era Renaisans, makanan sudah mempunyai gengsi tersendiri. Konon, banyaknya jumlah dan jenis makanan dalam sebuah gambar bisa menjadi tanda bahwa si pemilik lukisan hidupnya sangat berkecukupan. Pada zaman ini, ukuran prestise semacam itu tentu masih berlaku, bahwa semakin banyak terunggahnya foto makanan dan tempat makan bergengsi maka citra 'orang mampu' akan terlekatkan padanya. Kala itu banyak seniman membuat karya lukis still life yang menampilkan berbagai makanan, buah-buahan, dan minuman.

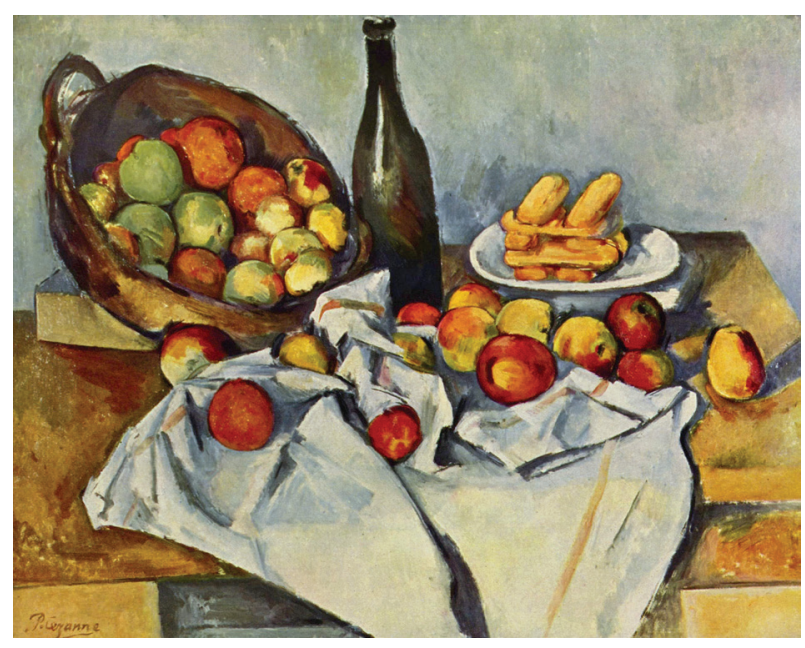

Lukisan karya Paul Cezanne

Sumber: (waldina.com, 2016)

Seiring dengan perkembangan teknologi fotografi digital, apresiasi orang terhadap makanan makin meningkat pula. Fotografi dalam sekejap bisa menghasilkan ratusan karya foto makanan sehingga akhirnya gaya penataan makanan dan tampilannya menjadi jauh lebih penting daripada makanan itu sendiri agar layak difoto dan diunggah ke Instagram. Penataan objek untuk difoto dan layak unggah ke Instagram pun kini diberi istilah khusus, yaitu Instagramable. Makanan-makanan yang tampak indah tersebut sengaja ditata demi menampilkan suatu pencitraan tertentu. Nilai kelayakan dianggap sebatas terlihat bagus dan indah untuk dipandang, tentu saja akan bernilai lebih bila hasil dan kualitas fotonya juga bagus dan sesuai kaidah fotografi. Dalam konteks ini fotografi menjadi instrumen pendongkrak status sosial seseorang tanpa dilihat dari peranti dan tekniknya secara lebih jauh. Objek foto adalah yang utama, yaitu makanan-makanan yang tertata cantik dan sangat camera ready, sedangkan rasa enak dan tidaknya makanan tersebut menjadi kurang penting. Dengan demikian, makanan sudah dipisahkan dari cita rasa yang sesungguhnya dan nilai kandungan gizinya karena hal tersebut tidak akan bisa divisualisasikan dengan tepat. Apresiasi tambahan akan secara otomatis tersematkan dalam foto tersebut bila terdapat informasi lokasi di mana foto tersebut diambil, entah berupa tagar atau add location. Tempat makan dan lokasi terkenal tentu saja akan menaikkan prestise foto tersebut dan mengklasifikasikan si pemilik akun ke dalam suatu golongan tertentu dalam bentuk apresiasi virtual.

Instagram yang merupakan ruang rupa virtual menghadirkan foto-foto makanan dari berbagai pemilik akunnya, dengan jenis makanan yang berbeda dan dengan teknik yang hampir serupa. Kebanyakan foto tersebut ditampilkan dengan sudut pandang bird eye view dan pencahayaan merata yang bisa didapatkan dari pencahayaan alami atau bisa juga dengan menggunakan flash. 


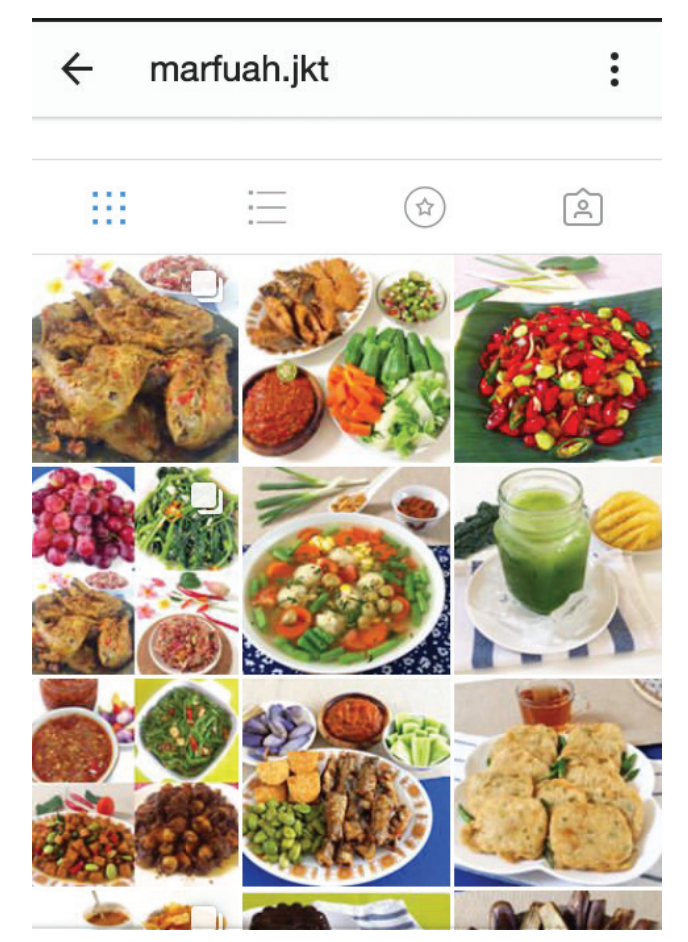

Nama akun IG: @marfuah.jkt Posts : 347

Followers :4,399
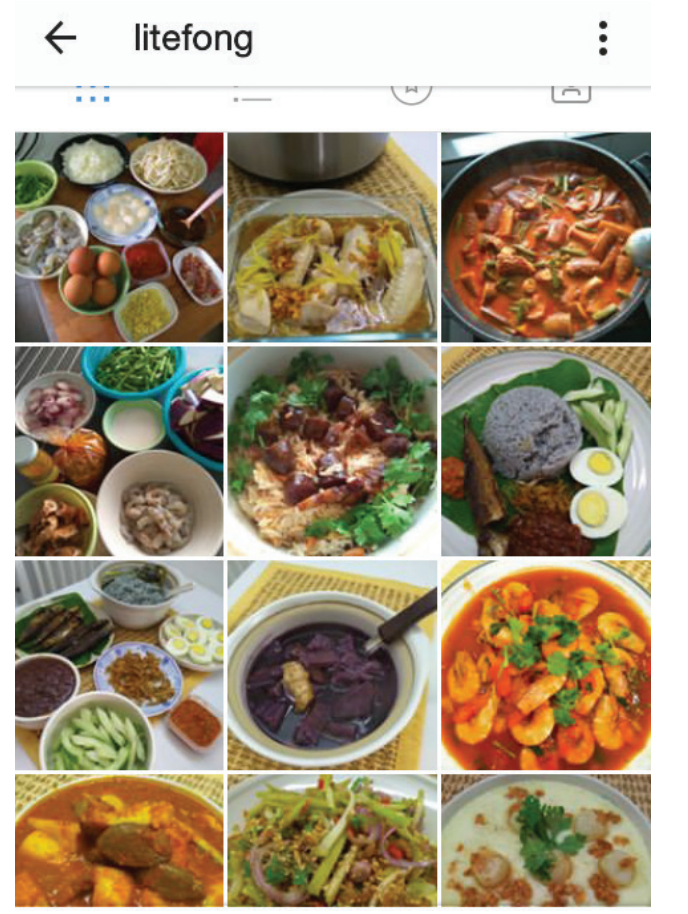

Nama akun IG: @litefong Posts: 1,293

Followers:6,076

Paparan visual yang tidak henti menyapa mata pemilik akun Instagram lambat laun menciptakan sebuah kelumrahan dan kewajaran yang akhirnya membentuk komunitas tersendiri, yaitu yang mereka (pengunggah foto makanan) sebut dengan food enthusiast alias penggemar makanan. Akun Instagram @marfuah.jkt dan @)litefong memiliki kemiripan dalam feeds unggahan foto-foto mereka. Keduanya sama-sama menampilkan masakan rumahan yang ditata dengan rapi, terlihat bersih, dan terlihat menggugah selera sehingga foto-foto mereka terlihat menarik. Kedua akun tersebut juga memiliki followers atau pengikut hingga ribuan orang.

Followers dalam Instagram merupakan indikator pencapaian 'status sosial' secara virtual, yang menandakan akun mereka digemari oleh banyak orang. Sangat disayangkan banyak sedikitnya followers tidak bisa diketahui dan tidak bisa diverifikasi, apakah memang angka tersebut didapatkan murni dari masing-masing individu yang mengikuti akun mereka, atau bisa jadi tingginya angka followers disebabkan angka tersebut dibeli dari para penjual jasa penambah followers dan likes. Fitur likes dalam Instagram juga sangat berpengaruh terhadap kredibilitas semu suatu akun. Dalam Instagram terdapat pula fitur repost app atau regram, yaitu untuk mengulang suatu unggahan foto yang berarti akan terjadi tindakan duplikasi dan simulasi berulang. Pengulangan suatu foto yang diunggah bisa saja tidak hanya sekali atau dua kali terulang, tetapi bisa hingga berkali-kali tanpa batas, bergantung pada keinginan seseorang untuk mengunggahnya ulang. Contoh simulasi pengulangan unggahan foto-foto dalam Instagram paling sering terjadi ketika pemilik suatu akun mengadakan sayembara, perlombaan, atau give away. Tanpa canggung dan berpikir panjang orang akan segera mengunggah ulang suatu foto tanpa pernah mengerti sesungguhnya apa yang ia apresiasi dan butuhkan.

Foto-foto makanan yang diunggah ke Instagram bukan saja tentang makanan yang dibeli atau dimakan, melainkan banyak juga pemilik akun yang mengunggah foto-foto hasil masakan mereka sehingga feeds Instagram mereka dipenuhi 
dengan beragam makanan hasil olahan mereka sendiri. Beberapa foto disertai dengan caption yang menjelaskan nama dan resep makanan serta lokasi suatu tempat makan, namun beberapa hanya berisi tagar-tagar saja.

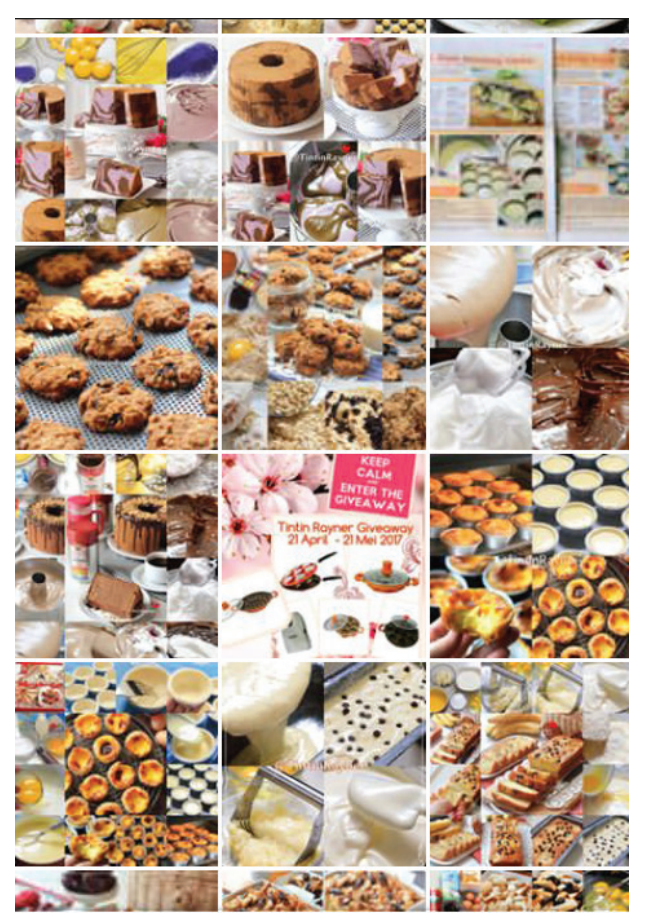

Nama akun IG : @tintinrayner Posts : 881 / Followers : 269.000

Sumber: (Rayner, 2017)

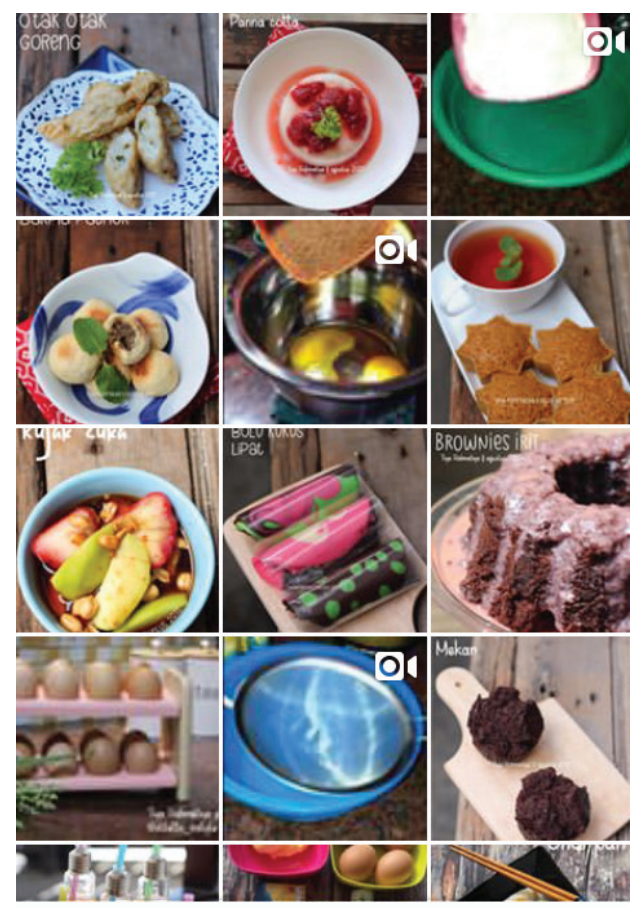

Nama akun IG : @tiyarahmatiya Posts : 2011 / Followers : 157.000 Sumber: (Rahmatiya, 2017)
Kedua akun Instagram tersebut, yaitu milik @tiyarahmatiyadan@tintinrayner merupakandua dari sekian banyak orang yang gemar memasak dan memiliki followers hingga ratusan ribu. Foto-foto yang mereka unggah sepertinya sangat menarik karena mampu mengumpulkan sekian banyak followers. Teks-teks yang mendampingi foto-foto di sana juga sangat menarik dan mengundang orang untuk membacanya, terutama mereka yang menyukai masak-memasak. Menurut Barthes, rangkaian kata dan kalimat merupakan sebuah anchoring, yang akan membantu gambar untuk menautkan artinya pada teks tertulis pun begitu sebaliknya sehingga keberadaan mereka akan saling dukung satu sama lain (Barthes, 1978).
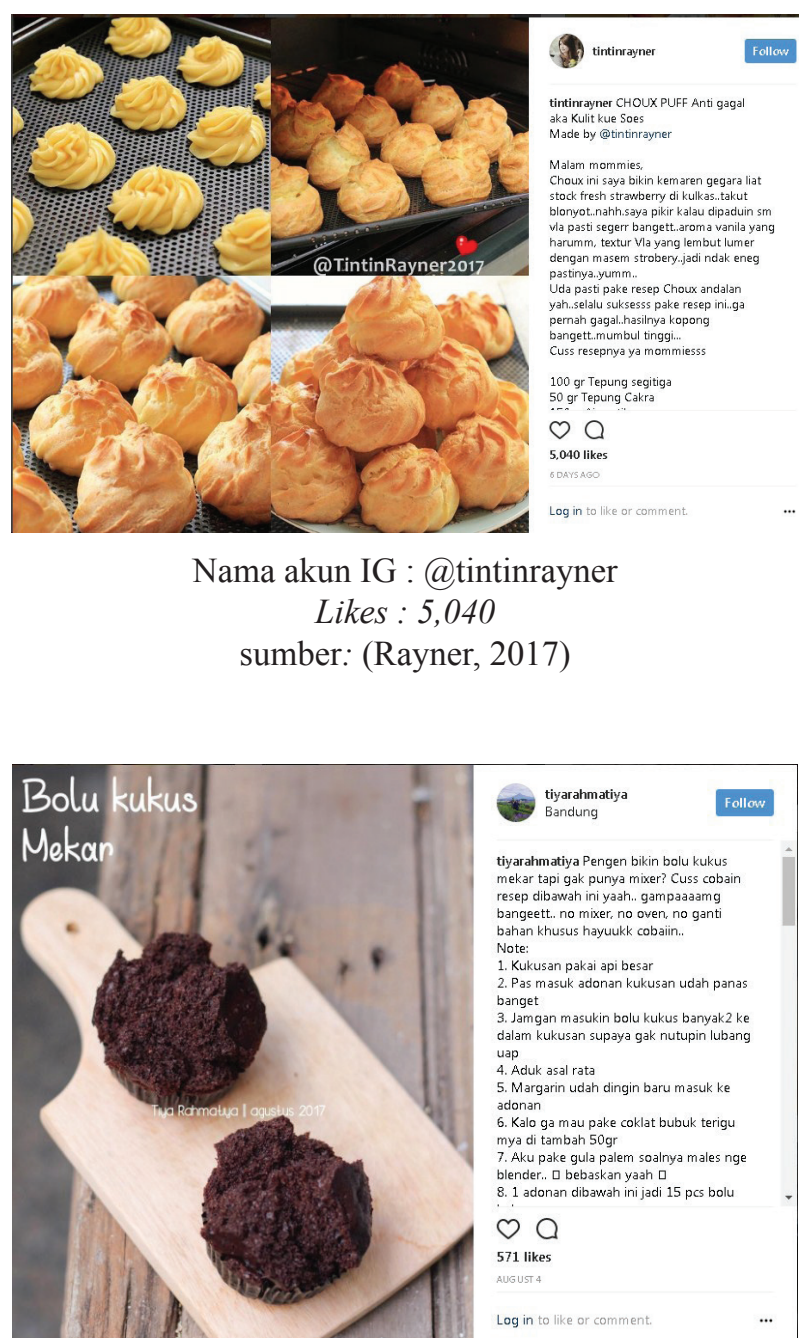

Nama akun IG : @tintinrayner Likes : 578

Sumber: (Rahmatiya, 2017) 
Kemurahhatian@tintinrayner dan @ tiyarahmatiya dalam berbagi resep masakan mampu menarik hati para orang untuk kemudian mem-follow dan memberi likes di tiap unggahan fotonya. Dalam dunia ilmu komunikasi, perilaku masyarakat yang mampu mengakses informasi secara mandiri melalui bantuan internet untuk kemudian mereproduksinya melalui proses share pernah dianalisis oleh Dentsu, seorang pakar komunikasi (Wirawan, 2016). Menurutnya, aktivitas share di dalam Instagram ini sangat jamak terjadi karena jangkauan internet sangatlah luas dan global sehingga cara tersebut sangat efektif untuk menyebarluaskan informasi. Aktivitas share melalui mediasi internet dengan karakterisiknya yang real time tentu saja sangat penting karena mereka akan bisa menjangkau follower secara lebih luas lagi. Atas peran besar internet, konsumsi terhadap visualisasi makanan dalam media fotografi akan berlangsung secara terus-menerus.

Melalui unggahan foto-foto makanan di Instagram, tingkat konsumerisme masyarakat cenderung meningkat tanpa mereka sadari. Mereka yang tidak pernah memasak atau tidak terbiasa membuat makanan sendiri menjadi ingin mencoba dengan menerapkan resep-resep dari akun Instagram. Resep yang berhasil dieksekusi dengan baik atau tidak biasanya akan segera diunggah ke akun mereka, dengan laporan keberhasilan ataupun kegagalannya. Pencapaian mereka sebenarnya bukan pada prosesnya, melainkan pada tetap eksisnya mereka dengan unggahan foto-fotonya yang mengikuti tren zaman dan kekinian. Pada saat representasi atau gambaran dari suatu objek menjadi lebih penting daripada objeknya sendiri maka sebuah simulasi telah tercipta. Penduplikasian yang sesungguhnya tidak pernah benar-benar ada membuat perbedaan antara duplikasi dan fakta itu sendiri menjadi kabur. Seseorang bisa menerapkan resep suatu masakan yang ia unduh dari Instagram dengan baik dan bisa dikatakan sukses, lalu ia membekukan momen hasil masakan tersebut ke dalam sebuah visualisasi foto yang kemudian ia unggah ke (lagi-lagi) Instagram. Alur yang demikian akan terus berulang dan berlanjut tanpa bisa dihentikan ataupun dicegah, apalagi jika akun tersebut di-follow oleh banyak orang seperti halnya dengan@tintinraynerdan@tiyarahmatiya.Dengan demikian, terciptalah sebuah simulakra - terjadinya representasi imitasi dan peniruan di sana-sini. Makna dan tanda direproduksi dalam dunia simulasi yang dilumrahkan.

Makan di restoran mewah ataupun di warung sederhana namun sedang kekinian, maka hal tersebut akan memiliki poin Instagramable pula. Visualisasi aktivitas bersantap di suatu tempat tersebut biasanya hadir dalam imaji makanan dan minuman yang terkadang ditunjang dengan beberapa asesoris yang akan mencitrakan jati diri seseorang. Foto-foto makanan berikut bisa dibaca sebagai sebuah upaya konstruksi diri si pemilik akun, tentang keberadaannya dengan informasi add location (Jamie's Italian di Bali dan Cengkir Heritage Restaurant di Yogyakarta) dan bagaimana mereka mendefinisikan diri mereka melalui tampilan foto makanan yang mereka unggah.

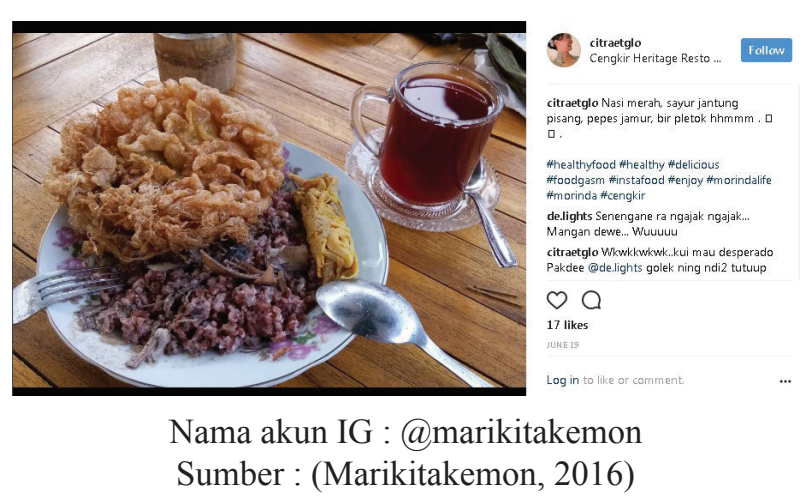




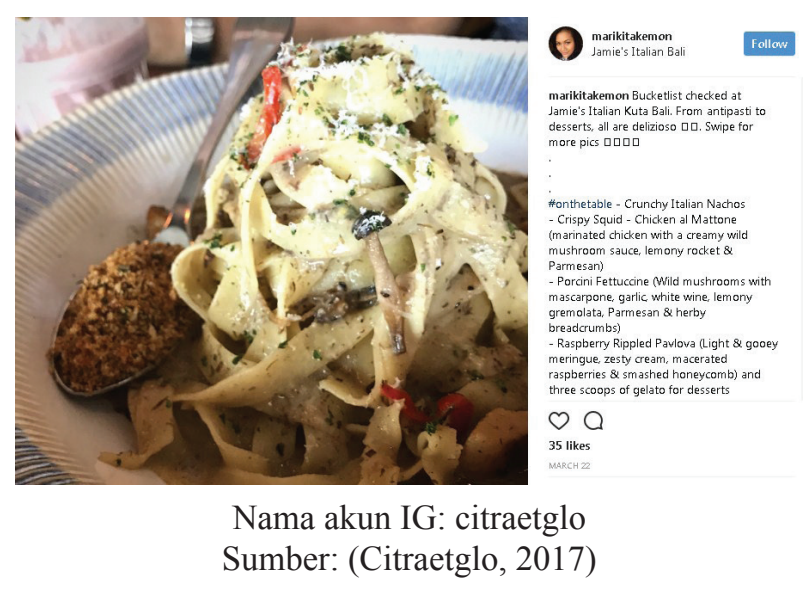

Ketika objek berupa makanan dengan segala pernik yang menunjang pencitraan objek tersebut dikonsumsi, maka sebetulnya yang dikonsumsi sekadar 'tanda' dan bukan makanan itu sendiri. Nasi merah dengan lauk-pauk pendampingnya bagai ingin menyuarakan bahwa si pengunggah foto (@) citraetglo) sangat menikmati suasana dan makanan yang bernuansa Jawa. Menu lengkap makanan Italia yang dihadirkan dalam foto dan caption @ marikitakemon seolah ingin menyampaikan kepada khalayak bahwa ia berada dalam suatu strata sosial tertentu, yang biasanya mengacu kepada kelas atas. Melalui objek-objek yang dikonsumsi, masing-masing individu menemukan hierarkinya, menemukan tempat dan komunitasnya tersendiri. Masyarakat konsumsi (consumer society) yang dicetuskan Baudrillard sepertinya memang benar adanya, bahwa mereka yang merasa berada dalam satu 'komunitas atau kelas' akan saling mendukung dan saling peduli (Baudrillard, 1995). Dukungan dan kepedulian tersebut muncul dalam bentuk komentar dan likes di foto yang diunggah. Semakin banyak komentar dan likes yang diberikan maka akan semakin kuatlah posisi dirinya dalam sebuah ruang virtual masyarakat konsumsi yang penuh simulasi dan simulakra.

Fotografi menciptakan kode-kode dan tatanan semu akan manipulasi tanda-tanda. Foto yang bagus dengan penyajian makanan yang bagus pula akan dianggap 'bernilai tinggi' sehingga akan menempatkan si pemilik foto ke suatu komunitas kelas atas. Hasil foto yang bagus bisa saja dihasilkan oleh seseorang yang giat bergelut mempelajari fotografi walaupun peranti fotografi yang ia gunakan hanya sederhana. Tatanan sajian makanan yang bagus kemungkinan besar dilakukan seseorang yang memiliki literasi terhadap food styling. Citraan visual yang dikonsumsi bisa saja bertolak belakang dengan realita yang ada sehingga terjadi pengaburan kelas dan status sosial di ranah media sosial. Fotografi makanan dalam multidimensi posmodernisme telah menjadi sebuah agen untuk membangun kode yang kemudian dikonsumsi dan dimaknai sebagai sebuah status sosial melalui simulasi dan simulakra yang telah melebur di keseharian kita. Simulasi dengan posmodernitasnya telah menciptakan dan melanggengkan kehidupan bersosial media, yang membuat orang ingin selalu eksis melalui unggahan foto-foto mereka di media sosial. Dorongan dan motivasi untuk selalu mengikuti perkembangan zaman di dunia kuliner akan mempertahankan seseorang berada pada posisi 'nyaman' secara virtual sebagai bagian dari masyarakat konsumsi yang global.

\section{Simpulan}

Dunia memerlukan cara berpikir dan memandang kehidupan dengan kacamata yang berbeda. Dari era modernisme, posmodernisme hadir untuk menentang modernisme itu sendiri, yang bagaikan membunuh rasionalitas manusia. Posmodernisme yang merupakan sebuah aliran pemikiran, lalu berkembang menjadi semacam paradigma baru yang merupakan antitesis dari modernisme - yang dinilai telah gagal dan tidak lagi relevan dengan perkembangan zaman. Posmodernisme muncul dengan berbagai instrumennya sebagai dukungan atas kebudayaan massal yang makin merasuki kehidupan manusia masa kini. 
Baudrillard berpendapat bahwa sesungguhnya tanda telah jauh dipisahkan dari objek yang direpresentasinya. Kemudian media seolah menggiatkan proses pemisahan tersebut hingga ambang nihilisme sehingga orang tidak lagi mengenali apa yang seharusnya mereka apresiasi. Dalam era simulasi ini, masyarakat dihadapkan pada makna kehidupan yang seolah-olah semu belaka tatkala tanda tidak lagi mewakili sesuatu apa pun, melainkan justru seolah-olah menciptakan kenyataan baru. Maka, ketika masyarakat dengan antusias menikmati sajian fotografi makanan yang terunggah di sekian banyak akun Instagram, tanpa disadari mereka tengah berjuang demi ego dan prestise mereka agar mampu menjadi bagian dari masyarakat konsumsi, entah pada hierarki dan kelas yang mana dipandang mampu untuk dijalaninya.

Kepemilikan akan sesuatu nilainya menjadi lebih penting dibandingkan fungsi atau arti objeknya itu sendiri. Dalam hal ini memiliki pengalaman yang kekinian: mencicip makanan popular, bersantap di tempat kuliner terkenal, memasak jenis makanan yang sedang jadi perbincangan di media sosial, memotret tiap makanan dan lokasi yang pernah dicoba dan tentu saja memiliki waktu untuk mengunggah dan membagikannya ke media sosial. Jadi, segala macam hal tadi dikonsumsi semata-mata demi suatu simbol status sosial. Dengan demikian, terciptalah sebuah simulakra terjadinya representasi imitasi dan peniruan di sanasini. Makna dan tanda direproduksi dalam dunia simulasi yang dilumrahkan sehingga arti dan fungsi dari makanan itu sendiri lepas dari gegap apresiasi khalayak.

\section{KEPUSTAKAAN}

\section{Buku}

Alasuutari, P. (1995). Researching Culture: Qualitative Method and Cultural Studies. California: SAGE.

Barthes, R. (1978). Roland Barthes Image Music Text. ( Stephen Heath, Ed.). New York: hill and wang.

Baudrillard, J. (1995). Simulacra and Simulation. Michigan: University of Michigan Press.

Berger, A. A. (2010). The Cultural Theorist's Book of Quotations. New York: Left Coast Press, Inc.

Edkins, J. and N. V.-W. (Ed. ). (2009). Critical Theorists and International Relations. Abingdon: Routledge.

Endraswara, S. (2003). Metodologi Penelitian Kebudayaan. Yogyakarta: Gadjah Mada University Press.

Fiske, J. (1990). Introduction to Communication Studies (Studies in Culture and Communiation). (2nd Ed.). New York: Routledge.

Hall, S. (1997). Representation: Cultural Representations and Signifying Practices (Culture, Media, and Identities Series). New York: SAGE.

Littlejohn, S. W. and K. A. F. (2008). Theories of Human Communication. 9th Ed. Belmont: Thomson Wardsworth.

McLuhan, M. (1964). Understanding Media: Extension of Man. New York: A Signet Book.

Sokal, A. and J. B. (1998). Intellectual Imposture. London: Profile Publishing.

Wirawan, F. A. W. \& P. D. H. (2016). Analisis AISAS MODEL Terhadap Product Placement dalam Film Indonesia Studi Kasus: Brand Kuliner di Film AADC 2. Rekam, Vol. 12 No (Oktober 2016). https://doi.org/http://dx.doi. org/10.24821/rekam.v12i2.1424 


\section{Pustaka Laman}

Citraetglo. (2017). cengkir heritage. Retrieved from https://www.Instagram.com/p/ BVhE9eygfSx/?taken-by=citraetglo

Komputer, G. I. (2015). Instagram. Retrieved January 1, 2017, from http://www. gudangilmukomputer.com/2015/12/sejarahdanperkembangan-aplikasi-sosial-mediaInstagram.html

Marikitakemon. (2016). marikitakemon. Retrieved September 1, 2017, from https://www. Instagram.com/p/BR8Ct0fjF 1N/?takenby=marikitakemon

Rahmatiya, T. (2017). tiya rahmatiya. Retrieved September 1, 2017, from https://www. Instagram.com/tiyarahmatiya/?hl=en

Rayner, T. (2017). tintin rayner. Retrieved September 1, 2017, from https://www.Instagram. com/p/BYx9QhkjJBG/?hl=en\&takenby=tintinrayner

Waldina.com. (2016). paul cezanne. Retrieved September 1, 2017, from https://waldina. com/2016/01/19/happy-177th-birthday-paulcezanne/ 